\title{
The Effects of Total Quality Management Practices and Marketing on Performance of SMEs. A Case of Selected Manufacturing Industries, Greece
}

\author{
Stavros Ioannis Kalogiannidis \\ Adjunct Lecturer \\ Department of Regional and Cross Border Development \\ University of Western Macedonia, Greece
}

Received: December 1, 2020 Accepted: January 4, 2021 Published: January 6, 2021

doi:10.5296/bms.v12i1.17995 URL: https://doi.org/10.5296/bms.v12i1.17995

\begin{abstract}
Most global studies have to a greater extent underscored the importance of Total quality management practices and some marketing aspects concerning organizational performance. Most studies have focused on establishing the level to which TQM practices influence customer satisfaction and not the whole organization. There is also little evidence on how marketing practices influence organizational performance. This study therefore seeks to assess the impact of Total Quality management practices and marketing on organizational performance. Data was collected from a sample size of 289 respondents who were employees of the different manufacturing industries in Greece. Data was analyzed using SPSS and Pearson's rank correlation coefficient was used to establish the relationship between study variables. The study findings confirmed the presence of a relationship between TQM practices and organizational performance. Similarly there was a positive relationship between marketing practices and organizational performance. The study concluded that the TQM practices and marketing are great influencers of quality hence should always be applied in organizations.
\end{abstract}

Keywords: Total Quality Management, Marketing, SMEs performance

\section{Background to the Study}

The field of Total Quality Management (TQM) has gained great attention in the recent past majorly due to its importance in enhancing the overall performance of an organization. The different practices of Total Quality Management play a significant role in improving the 
competitive advantage of organization and consequently enhancing the performance levels of such organizations (Anil \& Satish, 2016). TQM is associated with other important aspects in the growth of an organizations and these include; quality assurance and quality control. Most organizations that have management to control quality of their products have continuously registered high sales volumes which is corresponds to high levels of organizational growth. Most studies indicate that Total Quality Management is largely used as a tool to improve the general quality of products and services produced is offered by different manufacturing companies (Anil \& Satish, 2016).

Saudi Arabia ranks among the world's fastest growing countries concerning manufacturing products whereby it has an annual growth rate of $7.5 \%$ for the manufacturing sector. Saudi

Arabia's manufacturing sector accounts for about $10 \%$ of the country's GDP which is considered a significant contribution as compared to other sectors. The government of Saudi Arabia has financial and administrative support to the different companies involved in the manufacturing of different products majorly due to their contribution in the country's economic growth. Companies in the manufacturing sector are much concerned with producing highly quality products in order to maintain a better competitive advantage over their fellow players in the industry (Akhtar, Zameer \& Saeed, 2014).

Most past reports indicate that increased globalization has brought various operational problems in most of the manufacturing industries across the world and Saudi Arabia inclusive. In this case, organization face great difficulty in enhancing their performance and competition favorably with other players in the industry. Scholars however confirm that managing and maintaining quality in the organization is essential towards enhancing overall organizational performance (Singh, Darwish, \& Potočnik, 2016).

Coping with the challenges created by increased globalization requires different organizations or industries to adopt the most dynamic and effective strategies that will enable them to thrive in both domestic and international markets. Nassor (2015) indicates that one of the most effective operational practice that helps in improving an organization's competitive advantage is Total Quality Management since it supports employee commitment, customer engagement, employee training, employee-employer relations, and customer relationship management, among other aspects (Prajogo, \& Sohal, 2003).

Similarly improving marketing of the different products and services offered by organizations or industries requires organizations to adopt the most effective marketing strategies that focus on creating awareness among the potential customers concerning the validity of new or existing products. Organizations are always advised to maintain quality of the different products or services offered to customers. Studies indicate that product quality has a significant relationship with the level of sales generated in a particular period and this also has a great influence on organizational performance (Prajogo, \& Sohal, 2003). 


\subsection{Problem Statement}

The manufacturing sector plays a very important role in improving the country's GDP as well as improving the standards of living of the larger population in a country. Positive outcomes in the manufacturing industry greatly depends on the level of quality services and products provided by the industry as well as the nature of the internal and external environment in which the industry operates (Bhuiyan et al., 2014). Total Quality Management is concerned with the desire of an organization to offer highly quality products or services. Similarly most marketing practices used by organizations are aimed at creating awareness among potential customers concerning the available quality products and services (Farish, Anil, \& Satish, 2017). Most global studies have to a greater extent underscored the importance of Total quality management practices and some marketing aspects concerning organizational performance. Most studies have focused on establishing the level to which TQM practices influence customer satisfaction and not the whole organization. There is also little evidence on how marketing practices influence organizational performance. This study therefore seeks to assess the impact of Total Quality management practices and marketing on organizational performance.

\subsection{Purpose of the Study}

The study focused on establishing the effects of total quality management practices and marketing on performance of Organization using manufacturing industries in Saudi Arabia as the case study.

\subsection{Objectives of the Study}

To explore the relationship between employee involvement and organizational performance.

To establish the relationship between customer focus and organizational performance.

To determine the relationship between marketing practices and organizational performance

\subsection{Research Hypotheses}

$\mathrm{H}_{1}$ : There is a significant relationship between employee involvement and organizational performance.

$\mathrm{H}_{2}$ : There is a significant relationship between customer focus and organizational performance. $\mathrm{H}_{3}$ : There is a significant relationship between marketing practices and organizational performance.

\subsection{Significance of the Study}

The study findings will contribute greatly to the existing knowledge about the importance of Total

Quality Management practices and marketing on the performance of organizations 


\subsection{Conceptual Framework}

The conceptual framework in figure illustrates the link between dependent variables and the different independent variables. This includes how the different TQM practices (Customer focus and employee involvement relate with organizational performance and how marketing practices influence the performance of an organization.

\section{Literature Review}

This section presents a review of the different theoretical and empirical studies conducted in the post about Total Quality Management and marketing in relation to performance of organizations. The studies reviewed in this section were retrieved from different online data bases, journals, text books, and manuscripts from databases mostly Google Scholar and Web of Science.



Figure 1. Conceptual framework

\subsection{Theoretical Review}

The study is based on the contingency theory by Donaldson (1996). This theory asserts that organizations ought to fit their structure with different contingency factor in order to improve their general performance. Concerning this particular study, it meant that organizations have to relate their structure with the different aspects of Total Quality Management and quality marketing techniques in a bid to enhance performance. The structural contingency theory is based on the notion that there is no single desirable or most effective structure fir all organizations but rather organization have an obligation to match their stricture with the existing contingency factors as well as the operating environment if they are to achieve sustainable growth through improved performance. The most important contingency factors that include; technology, size of an organization, uncertainty, transparency, general accountability and critical assets.

In assessing the general relevance of the structural contingency theory concerning the enhancement of organizational performance, Al-Qahtani, Alshehri, \& Aziz (2015) applied the 5 stage structural adaptation to regain fit (SARFIT) model. First and foremost, an organization is considered to be in fit when it has successfully acclimatized to its entire environment. Under the second stage, there is exists contingency change that is greatly associated with 
different changes in the organizational environment. For the third stage, the organization is said to be in misfit and at this point, the performance suffers greatly.

In the fourth stage, the organization opts for structural adaption as a strategy for correcting the existing stage of misfit and consequently enhance the level of performance in the organization. The fifth that doubles as the final stage involves the organization achieving a new and desirable fit whereby a desirable level of performance is attained. Strategic choice plats a key role in the manufacturing industry of Saudi Arabia whereby industries bow to the decision of adopting a new structure that is compatible with the new level of contingency factor so as to avoid any performance losses that could arise from the misfit. It is therefore very important to examine the relationship that exists between the different aspects of Total Quality Management and marketing and performance of organization particularly manufacturing industries in Saudi Arabia (Akhtar,

Zameer \& Saeed, 2014).

\subsection{Empirical Review}

This section presents a review of different empirical studies conducted in the past concerning the different aspects of Total Quality Management and marketing and their impact on organizational performance

\subsection{Customer Focus and Organizational Performance}

Studies indicate that there is a great relationship between delivery of quality goods and services to customers and improved profitability of organizations which also enhances customer satisfaction. A study by Zehir et al. (2012) revealed that customer satisfaction is much dependent on the opinions or perceptions of customers towards a particular service or product. The study suggested that organizations can improve performance by focusing on the needs or demands of customers most especially by assessing the perceptions towards different products or services.

Singh Darwish \& Potočnik (2016) indicate that organizations must always establish strong customer relationships and consequently determine or measure customer needs and expectations as a basis for improving customer satisfaction and improving quality. The general availability of information concerning customer complaints helps managers to determine the level or extent to which customers are satisfied a certain service or products offered by the organization. Research indicates that the expectations of customers are so dynamic hence it is always essential for organizations to establish the current or updated customer expectations and consequently modify organizational activities based on the established expectations (García et al., 2014).

\subsection{Employee Commitment and Organizational Performance}

Employees play an important role in driving an organizations towards desired growth levels. It is however important to note that not all employees will adopt the different strategic 
managerial styles employed by an organization since some of these managerial styles and decisions affect employees indirectly. It is important that management keeps employees involved in the different decision making processes of an organization most especially concerning TQM practices since these encourage active participation and consequently help to improve organizational performance (García et al., 2014).

Upon establishing the required systems and tools for improving organizational performance, it is essential to engage employees in different forms of training to equip them with different skills important in enforcing change in organizations. García et al. (2014) indicate that trainings conducted on the right people have appeared very effective in minimizing wastage and misuse of different tool and techniques in organization especially those meant for improving organizational performance. Continued education and training of employees is very important in improving quality. During trainings, employees are encouraged to take more responsibility, engage in effective communication and consequently become more creative and innovative (Tasie, 2016).

\subsection{Organizational Performance}

Organizational performance is associated with the actual results or outcomes registered by an organization based on its total input or based on the set goals and objectives. Achieving improved organizational performance requires employees to showcase a high level of commitment that converts into enhanced productivity which in the longrun boost organizational performance. Most organizations measure their progress based on different aspects such as profits, level of assets, and the total return on investment. These normally determine an organization's level of financial performance which is essential in organizations growth. Organizations also measure performance based on the level of product market performance and shareholder return. According to Bhuiyan et al. (2014), product market performance is determined based on the levels of sales and market share of the organization whereas the shareholder return is assessed based on the total shareholder return registered in a particular period as well as the economic value added on the organization.

Several studies have been conducted in the past concerning the general performance in an organization and the different factors that help in improving performance (Al-Qahtani, Alshehri, \& Aziz, 2015). Studies also reveal that there are different aspects associated with organizational performance and these include; strategic planners, operations of an organization, finance performance, legal, and organizational development. In the recent past, very many organizations have focused on maintaining and controlling organizational performance using the balanced scorecard methodology. Under this methodology, the organizations focus on tracking performance and measuring it using different dimensions that include; financial performance, customer service, social responsibility and employee stewardship, among other dimensions (Al-Qahtani, Alshehri, \& Aziz, 2015).

Organizational performance is always considered the dependent variable in measuring the influence of Total Quality Management and marketing aspects in an organization. This broad 
construct is very important in assessing or evaluating the progress of organizations and comparing this progress with other competitors in the industry (Prajogo, \& Sohal, 2003).

\section{Methodology}

The study adopted a descriptive research design that involved using an online survey questionnaire to select data from different participants selected from the different manufacturing insurers across Saudi Arabia. The study employed probability sampling techniques whereby simple random sampling technique was used in selecting the different study participants. The reason for using the different employees of manufacturing industries in Greece is that they could possess great knowledge concerning the influence of Total Quality Management practices and marketing on organizational performance

A sample size of 289 participants randomly selected from the target population was used for this study. The sample size in the study was calculated using the Leslie Kish sample size formula:

$n=\frac{Z^{2} p q}{d^{2}}$

Where;

$\mathrm{n}=$ the required sample size

$\mathrm{z}=$ the standard normal value corresponding to the required level of confidence $(95 \%)=1.96$

$\mathrm{p}=$ the proportion of staff members in the organization, 25\%. (Since $\mathrm{p}$ is not known, 25\% will be used which gives appropriate sample size)

$q=(1-p)$ the proportion of individuals who aren't involved in quality management

$\mathrm{d}=$ The specified precision of the estimate $5 \%(0.05)$.

Therefore,

$n=\frac{Z^{2} p(1-p)}{d^{2}}$

$n=\frac{1.96^{2} * 0.25(1-0.25)}{0.05^{2}}$

$n=289$

Data collection was conducted by availing the survey questionnaire through an online data collection platform (Survey monkey) that involved engaging with the targeted sample size of participants. The data collected was sorted to rectify any existing errors using Microsoft excel. After sorting and coding the quantitative data, it was exported to SPPS for analysis. Presentation of the results was done using tables and graphs and interpretation was done based on frequencies and percentage. Pearson's rank correlation coefficient was based on to 
establish the relationship between the study variables.

\section{Results}

This part discusses the data finding upon the research results. The result consists of a general description of respondents, descriptive analysis of variables, classical assumption test results, hypothesis test results, and regression analysis.

\subsection{Demographic Profile of the Respondents}

The above analysis portrayed that $13.33 \%$ of the respondents were below 25 years, $48.89 \%$ respondents were within 26-34 years' bracket, 22.22\% representing 64 respondents were within 35-44 years' bracket, the remaining $15.56 \%$ representing 45 respondents were above 45 years of age who are likely to retire very soon.

The above table reveals that about 71.1 percent of the respondents were male, while 28.9 percent of them were female. Here, one will readily say that a greater proportion of the customers are male.

Table 1. Demographic Profile of the respondents

\section{Background Characteristics}

Frequencies $\quad$ Percentages (\%)

\section{Sex of respondents}

\begin{tabular}{lll}
\hline Male & 205 & 71.1 \\
\hline Female & 84 & 28.9 \\
\hline Age distribution & 38 & 13.3 \\
\hline Below 25 years & 141 & 48.9 \\
\hline $\mathbf{2 5 - 3 4}$ & 64 & 22.2 \\
\hline $\mathbf{3 5 - 4 4}$ & 45 & 15.6 \\
\hline $\mathbf{4 5}$ and above & & 48 \\
\hline Position of the respondents & 139 & 52 \\
\hline Owner & 150 & \\
\hline Manager & & 19 \\
\hline Age of the industry & 55 & 47 \\
\hline$<\mathbf{1}$ year & 136 & 34 \\
\hline $\mathbf{1 - 5}$ years & 98 & \\
\hline$>$ 5years & &
\end{tabular}

\section{Number of employees}




\begin{tabular}{lll}
\hline$\leq \mathbf{5}$ & 72 & 25 \\
\hline $\mathbf{6}-\mathbf{3 0}$ & 116 & 40 \\
\hline $\mathbf{3 1} \mathbf{- 7 5}$ & 64 & 22 \\
\hline Sales turnover & & \\
\hline$<$ US\$ 50000 & 98 & 34 \\
\hline US\$ 50001-100,000 & 165 & 57 \\
\hline$>$ US\$100,000 & 26 & 9 \\
\hline Total & 289 & 100 \\
\hline
\end{tabular}

Source: Survey (2020)

The over role description of the respondents contains the finding about gender, age, position of the respondent in the manufacturing industry, ownership, the amount of time the industries are running, the number of employees, and sales turnover of services, Saudi Arabia and all the necessary information were picked from the questionnaires.

\subsection{Analyses of Total Quality Management Practices}

The study sought to assess how Employee involvement enhances organizational performance and from Table 2, majority of the participants (48\%) strongly agreed that customer involvement which is a practice of Total Quality Management, has a great impact on organizational performance, while the least number of participants (7\%) were not sure whether the customer involvement influences performance levels in organizations.

Table 2. Opinions on employee involvement and employee performances

\begin{tabular}{lll}
\hline Statement & Frequency $(\mathbf{n = 2 8 9})$ & Percentage $(\%)$ \\
\hline Strongly agree & 96 & 48 \\
Agree & 76 & 38 \\
Not sure & 7 & 3.5 \\
Disagree & 12 & 6 \\
Strongly Disagree & 9 & 4.5 \\
Total & 289 & 100 \\
\hline
\end{tabular}

Source: Survey (2020).

The study also focused on establishing whether customer focus influences organizational performance. Majority of the participants (43\%) strongly agreed increased customer focus greatly enhances customer performance, while the least number of participants $(11 \%)$ were 
not sure whether focusing on customers most especially their expectations and needs, has any influence in organizational performance. The results confirm the fact that understanding the different demands of customers helps in driving quality whereby products are manufactured based on the existing or available demand. This in the longrun improves profitability and overall performance.

Table 3. Opinions on customer focus and organizational performance

\begin{tabular}{lll}
\hline Statement & Frequency $(\mathbf{n}=\mathbf{2 8 9})$ & Percentage $(\boldsymbol{\%})$ \\
\hline Strongly agree & 86 & 43 \\
Agree & 31 & 15.5 \\
Not sure & 11 & 5.5 \\
Disagree & 43 & 21.5 \\
Strongly Disagree & 29 & 14.5 \\
Total & 289 & 100 \\
\hline
\end{tabular}

Source: Survey (2020)

\subsection{Analysis of Marketing Practices on Organizational Performance}

Concerning the impact of different marketing practices on organizational performance, majority of the participants (91\%) strongly agreed that this style greatly impact on employees' performance, while no participant disagreed with this assertion.

Table 4. Opinions on marketing practices and organizational performance

\begin{tabular}{lll}
\hline Statement & Frequency $(\mathbf{n}=\mathbf{2 8 9})$ & Percentage $(\boldsymbol{\%})$ \\
\hline Strongly agree & 182 & 63.0 \\
Agree & 102 & 35.3 \\
Not sure & 5 & 1.7 \\
Disagree & 0 & 0 \\
Strongly Disagree & 0 & 0 \\
Total & 289 & 100 \\
\hline
\end{tabular}

Source: Survey (2020)

\subsection{Relationship Between Total Quality Management (TQM) Practices and Organizational} Performance

The study was aimed at establishing the relationship between Employee involvement and organizational' performance. A cross tabulation of the responses on Employee involvement and the effect of TQM on performance of organizations was conducted and the Pearson's rank correlation was carried out to establish the level of the relationship between the two variables. The results obtained and the subsequent Pearson's coefficient values are presented in table 5 . 
Table 5. Correlation Between Employee Involvement and Organizational Performance

\begin{tabular}{llll}
\hline & Employee & $\begin{array}{l}\text { Organizational } \\
\text { involvement }\end{array}$ & $\begin{array}{l}.247^{* *} \\
\text { performance }\end{array}$ \\
\hline Employee involvement & $\begin{array}{l}\text { Pearson Correlation } \\
\text { Sig. (2-tailed) }\end{array}$ & 1 & .011 \\
& $\mathrm{~N}$ & 289 & 289 \\
Organizational & $\begin{array}{l}\text { Pearson Correlation } \\
\text { performance }\end{array}$ & $\begin{array}{l}.247^{* *} \\
\text { Sig. (2-tailed) }\end{array}$ & 1 \\
& $\mathrm{~N}$ & .011 & \\
& & 289 & 289 \\
\hline
\end{tabular}

**. Correlation is significant at the 0.01 level (2-tailed).

After the cross tabulation and analysis, it was established that there is a significant relationship between participatory management style and employees' performance $\left(\mathrm{r}=0.247^{* *}\right.$, $\mathrm{n}=289, \mathrm{p}=.011$ ). The results clearly show that the involving employees in the different operations or activities of an organization such as decision making processes, has a great influence on organizational performance, which led to acceptance of the null hypothesis $\mathrm{H}_{1}$ that there is a significant relationship between employee involvement and organizational performance. The study was also meant to establish the relationship between customer and organizational performance. In this case, Pearson's rank correlation based analysis was conducted to establish this relationship and this would then help in establishing how customer relationships who understanding the expectations and demands of customers has an influence on organizational performance. The results obtained and the subsequent Pearson's coefficient values are presented in table 6.

Table 6. Correlation between customer focus and organizational performance

\begin{tabular}{llll}
\hline & & Customer focus & $\begin{array}{c}\text { Organizational } \\
\text { performance }\end{array}$ \\
\hline Customer focus & $\begin{array}{l}\text { Pearson Correlation } \\
\text { Sig. (2-tailed) }\end{array}$ & 1 & $.214^{* *}$ \\
& $\mathrm{~N}$ & 200 & .025 \\
& & 200 \\
Employee performance & Pearson Correlation & $.214^{* *}$ & 1 \\
& Sig. (2-tailed) & .025 & \\
& $\mathrm{~N}$ & 200 & 200 \\
\hline
\end{tabular}

**. Correlation is significant at the 0.01 level (2-tailed).

Source: Primary Data (2020). 
Following cross tabulation and correlational analysis it was established that there is a positive relationship between autocratic management style and employees' performance $\left(r=0.326^{* *}\right.$, $\mathrm{n}=200, \mathrm{p}=.025$ ). The results clearly show that the different dynamics of autocratic management style greatly influence the performance of employees in organizations. These results also led to the acceptance of the null hypothesis $\mathrm{H}_{2}$ that there is a significant relationship between customer focus and organizational performance.

The relationship between marketing practices and organizational performance was also established based on Pearson's rank correlation coefficient values as are presented in table 7.

Table 7. Correlation between marketing practices and organizational performance

\begin{tabular}{llll}
\hline & & Customer focus & $\begin{array}{l}\text { Organizational } \\
\text { performance }\end{array}$ \\
\hline Marketing practices & $\begin{array}{l}\text { Pearson Correlation } \\
\text { Sig. (2-tailed) } \\
\mathrm{N}\end{array}$ & 1 & $.431^{* *}$ \\
& & .021 \\
Organizational & Pearson Correlation & $.431^{* *}$ & 289 \\
performance & Sig. (2-tailed) & .021 & 1 \\
& $\mathrm{~N}$ & 289 & \\
& & 289 & 289 \\
\hline
\end{tabular}

**. Correlation is significant at the 0.01 level (2-tailed).

Source: Primary Data (2020)

The results showed that there is a positive and significant relationship between marketing practices and organizational performance $\left(r=0.431^{* *}, n=289, p=.021\right)$. In this case, the different strategic marketing practices such as using different promotional campaigns, have a great influence on the general performance of an organization. These results also led to the acceptance of the null hypothesis $\mathrm{H}_{3}$ that there is a significant relationship between marketing practices and organizational performance.

\section{Discussion}

The study clearly show that Total Quality Management (TQM) and marketing greatly influence the level of organizational performance through various ways. The study findings established that the different aspects of TQM most especially employee commitment and customer focus are great drivers of quality in an organization which is directly associated with improved productivity and better organizational performance (Kalogiannidis et al. 2020).

The findings indicated that there is a positive and significant relationship between the different aspects of marketing and improved organizational performance. For, the literature 
review most scholars assert that marketing drives quality, improves sales and consequently creates a large number of loyal customers who have a direct influence of organizational performance (Tasie, 2016). This is attributed to the fact that the level of organizational growth and performance of most organizations is much dependent on the customer base. According (Kalogiannidis, 2020) appropriate business communication is a very essential tool for attaining greater performance in an organization.

\section{Conclusion}

The study findings confirm that there is a positive relationship between Total Quality Management and the general performance of manufacturing organizations. The results also confirm that marketing of products improves on their sales which consequently enhances the general performance of an organization. In relation employee involvement, the study concluded that committed employees and getting them involved in different organizational operations greatly helps the organization to register improved performance and growth. The study concluded that customer focus most especially based on improved customer relationships, have a very significant effect of organizational performance. This is because increased customer focus since it managers to understand the different expectations, needs and demands of customers and address them accordingly towards improving organizational performance.

\subsection{Recommendations}

Since the study findings have clearly shown that the different practices of TQM most especially employee involvement and customer focus, have been found to have a significant and positive relationship with organizational performance, it is advisable that manufacturing companies adopt TQM as a quality management model. Furthermore based on the importance of strategic marketing on improving quality of products and enhancing organizational performance, it very important for manufacturing companies to apply very effective marketing strategies inorder to continuously grow their customer base, increase sales and improve organizational performance.

\subsection{Areas for Future Research}

This study only focused on a few aspects of Total Quality Management and marketing and their influence on organizational performance. It is advisable that future studies focus on other practices of TQM such as process-centeredness, integrated system, continual improvement, and consequently establish their impact on organizational performance most especially in the manufacturing industry. 


\section{References}

Akhtar, S., Zameer, H., \& Saeed, R. (2014). Impact of total quality management on the performance of service organizations in Pakistan. International Journal of Academic $\begin{array}{lllll}\text { Research in Economics and Management Sciences, } & 109 .\end{array}$ https://doi.org/10.6007/IJAREMS/v3-i6/1350

Al-Qahtani, N. D., Alshehri, S. S. A., \& Aziz, A. A. (2015). The impact of Total Quality Management on organizational performance. European Journal of Business and Management, 7(36), 119-127.

Anil, A. P., \& Satish, K. P. (2016). Investigating the relationship between TQM practices and Firm's performance: A conceptual framework for Indian organizations. Procedia Technology, 24(555), 554-561. https://doi.org/10.1016/j.protcy.2016.05.103

Bhuiyan, M., Hossain, Z., Rahman, M., \& Shahnewaz, S. T. (2014). An Empirical Study on Total Quality Management Practices in Some Selected Manufacturing Companies in Bangladesh.

Farish, K., Anil, A. P., \& Satish, K. (2017). Effect of TQM practices on financial performance through innovation performance-in Indian manufacturing context. International Research Journal of Engineering and Technology, 4(7), 2649-2655.

García, J. Á., Rama, M. D. L. C. D. R., \& Alonso, M. V. (2014). The Effects of Quality Management Practices on Key Results: questionnaires sample for the industry of tourist accommodation in Spain. Revista Brasileira de Gestão de Negócios, 16(52), 351-373.

Kalogiannidis , S., Melfou, K., \& Papaevangelou, O. (2020). Global Marketing Strategic Approaches on Multi National Companies Product Development. International Journal of Scientific Research and Management, 8(12), 2084-2090. https://doi.org/10.18535/ijsrm/v8i12.em08

Kalogiannidis, S. (2020). Impact of Effective Business Communication on Employee Performance. European Journal of Business and Management Research, 5(6). https://doi.org/10.24018/ejbmr.2020.5.6.631

Kalogiannidis, S., \& Mavratzas, S (2020). Impact of marketing mix strategies effective product development issues in MNCs/Retail. International Journal of Business Marketing and Management (IJBMM), 5(12), December 2020, 118-125. ISSN: 2456-4559.

Kalogiannidis, S., \& Papaevangelou, O. (2020). Impact of Business Communication on the Performance of Adult Trainees. International Journal of Academic Research in Progressive Education and Development, 9(3), 213-222.

Mohammed, A., Alharthi, A. A. M., Alharthi, D. K., Alhabashi, W. S., \& Hasan, S. H. (2014). Organization Performance Improvement using TQM. International Journal of Computer Applications, 108(9). https://doi.org/10.5120/18942-0361 


\section{Macrothink}

Nassor, F. M. (2015). The Impacts of ISO 9001 Quality Management System Implementation on Employees' Performance of Pension Funds in Tanzania: A Case of National Social Security Fund (NSSF) (Doctoral dissertation, The Open University of Tanzania).

Prajogo, D. I., \& Sohal, A. S. (2003). The relationship between TQM practices, quality performance, and innovation performance. International journal of quality \& reliability management. https://doi.org/10.1108/02656710310493625

Singh, S., Darwish, T. K., \& Potočnik, K. (2016). Measuring organizational performance: A case for subjective measures. British Journal of Management, 27(1), 214-224. https://doi.org/10.1111/1467-8551.12126

Tasie, G. (2016). An exploratory review of total quality management and organizational performance. International Journal of Business and Law Research, 4(1), 39-45.

Zehir, C., Ertosun, Ö. G., Zehir, S., \& Müceldilli, B. (2012). Total quality management practices' effects on quality performance and innovative performance. Procedia-Social and Behavioral Sciences, 41, 273-280. https://doi.org/10.1016/j.sbspro.2012.04.031

\section{Copyright}

Copyright for this article is retained by the author(s), with first publication rights granted to the journal.

This is an open-access article distributed under the terms and conditions of the Creative Commons Attribution license (http://creativecommons.org/licenses/by/4.0/). 